\title{
PERANCANGAN SISTEM REKOMENDASI MENGGUNAKAN METODE COLLABORATIVE FILTERING DENGAN STUDI KASUS PERANCANGAN WEBSITE REKOMENDASI FILM
}

\author{
Michael Mahendra Wiputra ${ }^{1}$ \\ Yusup Jauhari Shandi ${ }^{2}$ \\ ${ }^{1,2}$ Sekolah Tinggi Manajemen Informatika dan Komputer LIKMI \\ Jl. Ir. H. Juanda no 96 Bandung \\ ujshandi@gmail.com ${ }^{2}$
}

\begin{abstract}
ABSTRAK
Dalam era digitalisasi yang berkembang membuat data dan informasi bisa didapatkan mudah dan cepat, hal ini dapat menyebabkan informasi yang tersedia sangat banyak dan membuat orang kesulitan dalam menentukan pilihan. Sistem rekomendasi berperan penting untuk menyediakan informasi sesuai dengan minat user.

Salah satu metode yang bisa digunakan dalam membangun sistem rekomendasi adalah dengan menggunakan metode collaborative filtering, pada penelitian ini metode tersebut diterapkan dengan pada sebuah website rekomendasi film. Pada website ini sistem rekomendasi user-based collaborative filtering digunakan untuk menampilkan rekomendasi pada tampilan utama.

Metode ini akan mencari pengguna yang memiliki kemiripan paling dekat dalam minat akan suatu kelompok film tertentu (user-neighborhood), dan memberikan rekomendasi film bedasarkan hal tersebut. Jika suatu film disukai oleh seorang pengguna A, maka film tersebut juga kemungkinan akan disukai oleh pengguna $\mathrm{B}$ yang memiliki kemiripan dengan pengguna A.

Sistem rekomendasi akan menampilkan rekomendasi ketika pengguna telah memenuhi kriteria, dikarenakan sistem yang dibuat merupakan sistem rekomendasi terpesonalisasi dimana perhitungan rekomendasi didasarkan pada perhitungan nilai similarity antar pengguna yang telah melakukan penilaian terhadap suatu film sehingga dibutuhkan data awal untuk mengetahui preferensi dan minat pengguna yang akan digunakan untuk perhitungan prediksi rekomendasi.
\end{abstract}

Kata kunci : collaborative filtering, rekomendasi.

\section{PENDAHULUAN}

Berbagai macam konten hiburan digital saat ini banyak bermunculan dan menggantikan media hiburan konvensional. Pergantian juga terjadi pada sektor-sektor lainnya seperti munculnya layanan jual-beli online seperti marketplace dan e-commerce, ataupun munculnya penjualan layanan tur yang berbasis online yang menggantikan penjualan konvensional. Terjadinya perubahan landasan berpikir dan kebutuhan manusia akan sumber informasi ataupun hiburan yang sebelumnya berbentuk fisik menjadi sumber informasi dan hiburan dalam bentuk digital telah merepresentasikan era digital. Namun informasi digital yang terus berkembang seiring dengan perkembangan waktu menyebabkan tumpukan informasi yang sangat besar. 
Penyedia layanan digital ingin menyediakan layanan miliknya tepat sasaran, seperti penyedia layanan streaming film yang ingin menyediakan konten-konten miliknya sesuai dengan minat penggunanya. Disisi lain manusia mudah dipengaruhi oleh rekomendasirekomendasi dari berbagai macam sumber seperti teman, rekan kerja, atau oleh orang tua. Rekomendasi mampu membuat seseorang berbuat sesuatu, atau membeli sesuatu yang di rekomendasikan tanpa mereka sadari.

\section{TUJUAN DAN MANFAAT PENELITIAN.}

Tujuan penelitian ini adalah sebagai berikut:

a. Mengetahui cara kerja sistem rekomendasi neighborhood-based collaborative filtering

b. Mengetahui cara kerja sistem rekomendasi dalam merekomendasikan konten yang sesuai dengan minat masing-masing pengguna

c. Membangun sistem rekomendasi menggunakan metode collaborative filtering yang diimplementasikan menjadi website penyedia rekomendasi film.

d. Sistem rekomendasi mampu diimplementasikan pada website lainnya.

Adapun kegunaan atau manfaat dari penelitian ini adalah :

a. Mempermudah penyedia layanan digital skala kecil dalam penyajian informasi yang tepat sasaran dengan biaya yang tidak terlalu besar.

b. Sistem rekomendasi mampu memberikan rekomendasi yang terpersonalisasi sehingga mempermudah dan mempercepat pengguna dalam menemukan informasi yang relevan.

c. Sistem rekomendasi dapat diterapkan pada website-website lainnya yang membutuhkan penyajian data yang tepat sasaran seperti website e-commerce dan website penyedia konten.

\section{SISTEM REKOMENDASI}

Sistem rekomendasi merupakan sistem perangkat lunak yang dapat membuat rekomendasi ataupun membuat saran akan item-item yang sesuai kepada pengguna, item adalah istilah umum yang digunakan untuk menunjukkan apa yang direkomendasikan sistem kepada pengguna (Ricci, Rokach \& Shapira, 2011:1). Tujuan utama dari sistem rekomendasi adalah pengembangan sistem yang mendukung pengguna dalam membuat pilihan atau keputusan dan menyediakan akses rekomendasi sesuai prefrensi dan minat pengguna untuk komunitas besar. Tantangan dari sistem rekomendasi adalah mampu menyediakan rekomendasi yang terjangkau, terpesonalisasi, dan berkualitas baik. Sistem rekomendasi berkerja dengan memahami selera pengguna dan menemukan konten baru yang diharapkan oleh pengguna secara otomatis.

Sistem rekomendasi memiliki tiga komponen utama agar dapat terbentuknya suatu rekomendasi, yaitu users, items, dan transactions (Ricci, Rokach, \& Shapira, 2011:8). Items merupakan objek yang direkomendasikan. Items bisa diklasifikasikan menurut karakternya berdasarkan kerumitannya, nilainya, ataupun kegunaannya. Users dari sistem rekomendasi mungkin memiliki karakteristik dan tujuan yang berbeda-beda. Users dapat dideskripsikan berdasarkan data pola kebiasaan, seperti pola kebiasaan pengguna dalam pencarian film (didalam sistem rekomendasi layanan film online), pola kebiasan pengguna dalam menjelajah internet (didalam sistem rekomendasi web). Transactions pada umumnya mengacu pada interaksi yang terekam antara items dan users, transaksi yang paling popular digunakan untuk menggambarkan interaksi antara user dan item adalah rating. 


\subsection{USER-BASED COLLABORATIVE FILTERING}

Sistem rekomendasi user-based collaborative filtering memperkirakan apa yang akan disukai pengguna berdasarkan kesamaannya dengan pengguna lain atau biasa disebut neighborhood users (Jia, Yang, Gao \& Chen, 2015:22). User-based collaborative filtering ini berdasarkan konsep atau asumsi bahwa pengguna yang memiliki perilaku serupa akan memiliki kebiasaan yang serupa juga. Seorang pengguna A yang memiliki pendapat yang sama dengan pengguna $\mathrm{B}$ terhadap suatu informasi $\mathrm{x}$, pendapat A memiliki kemungkinan yang lebih besar akan sama dengan pendapat B terhadap suatu informasi y jika dibandingan dengan pengguna lain yang dipilih secara acak (Gandhi \& Gheewala, 2017:457).

Metode ini bekerja dengan memprediksi dan merekomendasikan item yang mungkin cocok bagi penguna berdasarkan perhitungan kemiripan antara profil kebiasaan suatu pengguna dengan profil kebiasaan pengguna yang memiliki ketertarikan atau kebiasaan sejenis.

\subsection{ITEM-BASED COLLABORATIVE FILTERING}

Item-based collaborative filtering membuat prediksi sejumlah item berdasarkan perhitungan korelasi suatu item dengan item lainnya yang telah dirating oleh pengguna atau biasa disebut neighborhood items (Suteja \& Guritno, 2017:2). Metode item-based collaborative filtering bekerja pada item yang telah memiliki penilaian, yang kemudian akan mengelompokan item berdasarkan kemiripan antar item. Pengguna berkemungkinan lebih besar akan menyukai item-item sejenis yang berkorelasi dengan item-item yang telah disukainya.

Item-based collaborative filtering merupakan metode dalam sistem rekomendasi yang pada umumnya digunakan apabila jumlah data item yang ada jauh lebih sedikit jika dibandingkan dengan jumlah pengguna yang ada. User-based collaborative filtering relatif lebih akurat, disisi lain item-based collaborative filtering relatif lebih stabil (Sun \& Huang, 2013:91). Item-neighborhood diilustrasikan melalui Gambar 1 dengan lingkaran berwarna biru, sedangkan user-neighborhood diilustrasikan menggunakan lingkaran berwarna hitam.

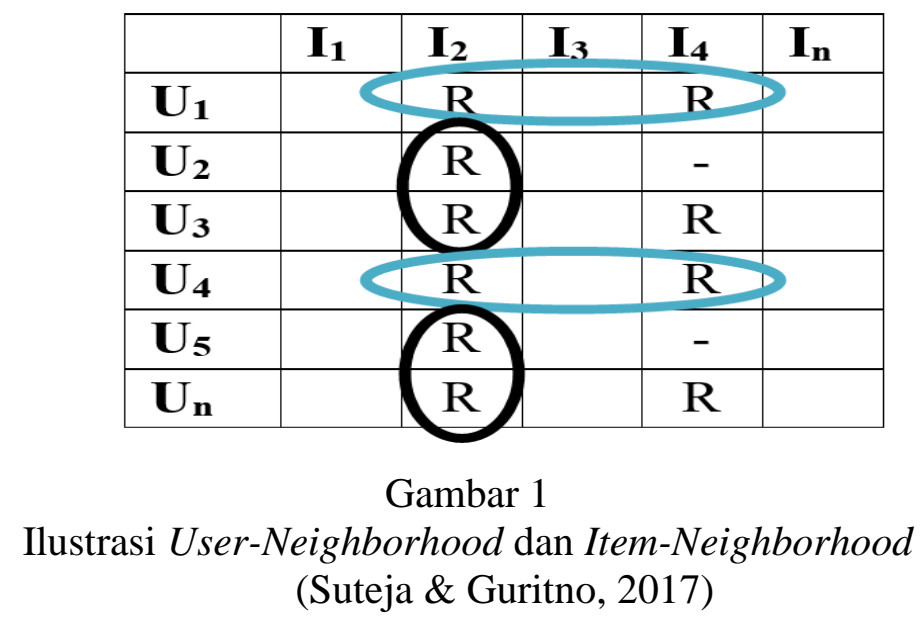

\subsection{MULTICRITERIA COLLABORATIVE FILTERING}

Sistem rekomendasi tradisional sejauh ini diterapkan dengan hanya menggunakan satu input penilaian rating untuk mewakili pendapat pengguna. Permasalahan terjadi ketika suatu pengguna memberikan penilaian yang sama dengan pengguna yang lain namun kriteria yang digunakan berbeda sehingga dapat memberikan hasil rekomendasi yang 
kurang tepat. Sebagai contoh, seorang pengguna memberikan nilai dengan skala lima dari lima terhadap suatu item, dapat terjadi permasalahan ketika pengguna lain yang memberikan nilai lima namun pengguna yang lain tersebut berdasarkan kriteria yang berbeda. Permasalahan tersebut biasa disebut "without distinction of interest problem", untuk menyelesaikan permasalahan tersebut terdapat sebuah ide yang ditawarkan, yaitu multicriteria collaborative filtering (Wiranto, Winarko, Hartati, \& Wardoyo, 2014:53).

Multicriteria collaborative filtering merupakan variasi pendekatan collaborative filtering yang menggunakan lebih dari satu kriteria sehingga bisa menyediakan informasi yang lebih banyak tentang preferensi pengguna dari aspek yang berbeda jika dibandingkan dengan sistem rekomendasi tradisional (Liu, Mehandjiev, \& Xu, 2011:78).

Multi-criteria collaborative filtering membuat rekomendasi diawali dengan pembuatan matrix yang berisi rating penilaian dari semua pengguna terhadap semua item. Pada tahap kedua, perhitungan jarak antar pengguna maupun item dilakukan. Untuk perhitungan jarak antar objek bisa digunakan berbagai macam metode perhitungan jarak antar objek seperti City Block, Lorentzian, Euclidean, ataupun sejenisnya. Perhitungan jarak antar objek pada studi kasus ini dihitung menggunakan persamaan Euclidean distance karena pertimbangan efisiensi waktu komputasi, dan hasil perhitungan empiris yang baik (Giusti \& Batista, 2013:87). Euclidean distance bekerja dengan cara mengukur jarak antar objek, nilai perhitungan jarak yang lebih kecil menandakan objek tersebut semakin mirip. Rumus persamaan euclidean distance pada kasus perhitungan kemiripan antar pengguna ditunjukan pada persamaan berikut: (Suteja \& Guritno, 2017)

$$
\mathrm{d}(\mathrm{u}, \mathrm{v})=\sqrt{\sum_{i=1}^{n}\left(\mathrm{ru}_{\mathrm{i}} \mathrm{i}-\mathrm{r}^{\prime} \mathrm{v}_{\mathrm{i}} \mathrm{i}\right)^{2}}
$$

Keterangan :

$$
\begin{array}{lll}
d(u, v) & = & \text { jarak antar pengguna } \\
\mathrm{n} & = & \text { jumlah kriteria penilaian yang digunakan pada sistem } \\
i & = & \text { iterator yang dimulai dari nilai } 1 \text { hingga } \mathrm{n} \\
r u, i & = & \text { nilai rating objek u untuk objek yang ke-i } \\
r v, i^{\prime} & = & \text { nilai rating objek } \mathrm{v} \text { untuk objek yang ke-i }
\end{array}
$$

Setelah mendapatkan hasil perhitunagan jarak antar objek dari persamaan euclidean distance, dihitung rata-rata jarak antar objek pada setiap objek sehingga mendapatkan total distance. Nilai dari total distance digunakan untuk perhitungan nilai kemiripan(similarity) yang dinyatakan dalam $1 /(1+$ total distance $)$, ketika nilai semakin tinggi memiliki arti bahwa hubungan antar objek semakin dekat atau kemiripan semakin tinggi.

Pada sistem rekomendasi user-based collaborative filtering agar dapat menentukan rekomendasi item untuk pengguna maka akan dilakukan perhitungan prediksi rating dengan pencarian pengguna lainnya yang memiliki nilai similarity tertinggi. Pengguna yang memiliki nilai similarity dengan pengguna lain yang tinggi bisa dikatakan bahwa kedua pengguna tersebut dapat dikelompokan sebagai pengguna yang memiliki ketertarikan sejenis sehingga pengguna dalam kelompok tersebut bisa saling memberikan rekomendasi. Perhitungan prediksi dilakukan menggunakan rumus similarity-based prediction yang ditunjukan pada persamaan berikut (Wiranto, Winarko, Hartati, \& Wardoyo, 2014, p. 55): 


$$
P(u, i)=\bar{R}(u ; *)+\frac{\left.\left.\sum \mathrm{v} \in \mathrm{N} \mathrm{s}(\mathrm{u}, \mathrm{v}) \overline{\mathrm{R}}(\mathrm{v}, \mathrm{i})-\overline{\mathrm{R}}(\mathrm{v}, *)\right)\right)}{\sum \mathrm{v} \in \mathrm{N}(|\mathrm{s}(\mathrm{u}, \mathrm{v})|)}
$$

Keterangan :

$$
\begin{aligned}
& P(u, i)=\quad \text { nilai prediksi pengguna } \mathrm{u} \text { terhadap item } \mathrm{i} \\
& \overline{R(} u, *)=\quad \text { nilai rata-rata rating pengguna } \mathrm{u} \\
& \overline{R(v, *)}=\quad \text { nilai rata-rata rating pengguna } \mathrm{V} \\
& \overline{R(v, i)}=\quad \text { nilai rating pengguna } \mathrm{v} \text { untuk item } \mathrm{i} \\
& s(u, v)=\quad \text { nilai similarity pengguna } \\
& v \quad=\quad \text { anggota dari } \mathrm{N} \\
& N=\text { kumpulan pengguna dengan nilai similarity dua terbesar }
\end{aligned}
$$

\section{ANALISIS DAN PERANCANGAN}

Proses rekomendasi dimulai dengan pengumpulan data penilaian pengguna yang hasilnya disimpan di database untuk dijadikan input, input dari database selanjutnya akan dibuat menjadi matrix yang berisi rating penilaian, dibuat agar mempermudah proses perhitungan. Matrix kemudian di iterasi untuk pencarian data penilaian seorang pengguna dengan data penilaian pengguna lainnya yang menilai film yang sama atau biasa disebut user-neighborhood. Data user-neighborhood yang ditemukan kemudian akan digunakan untuk menghitung jarak antara pengguna dengan menggunakan rumus euclidean distance.

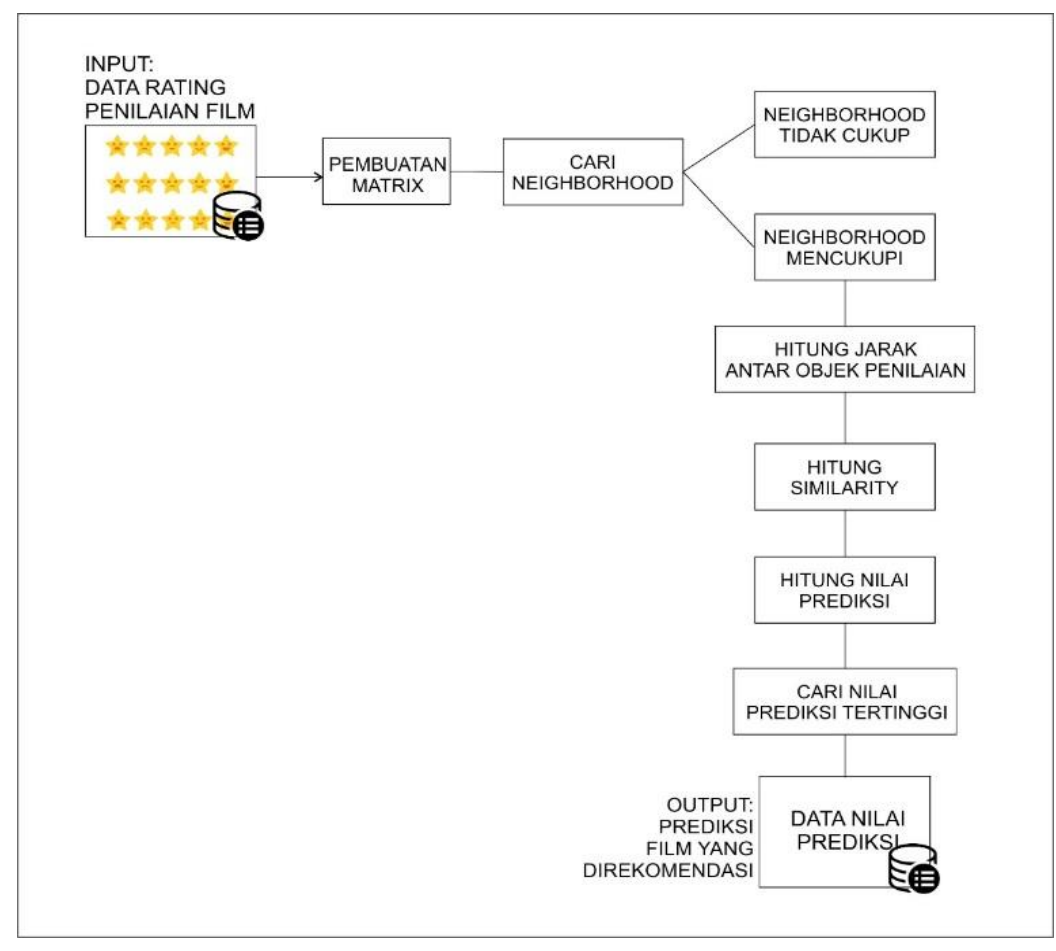

Gambar 2

Proses Pembuatan Rekomendasi Berdasarkan User-Based Collaborative Filtering 
Hasil dari perhitungan rata-rata jarak antara user-neighborhood digunakan sebagai data untuk mencari kemiripan atau similarity. Similarity antara dua pengguna ditentukan dalam $1 /(1+$ distance $)$, hal ini dikarenakan ketika jarak yang di hitung menggunakan euclidean distance semakin dekat menandakan bahwa kedua buah objek perhitungan tersebut semakin mirip atau similar. Nilai similarity tertinggi yang dihasilkan akan digunakan untuk perhitungan prediksi nilai rating film yang belum pernah di input oleh pengguna dengan menggunakan rumus similarity based prediction. Data prediksi yang dihasilkan kemudian disimpan di database untuk ditampilkan ketika dibutuhkan.

Item-based collaborative filtering digunakan untuk memberikan rekomendasi filmfilm sejenis pada suatu film. Film-film sejenis didapatkan dari perhitungan nilai similarity antar film.

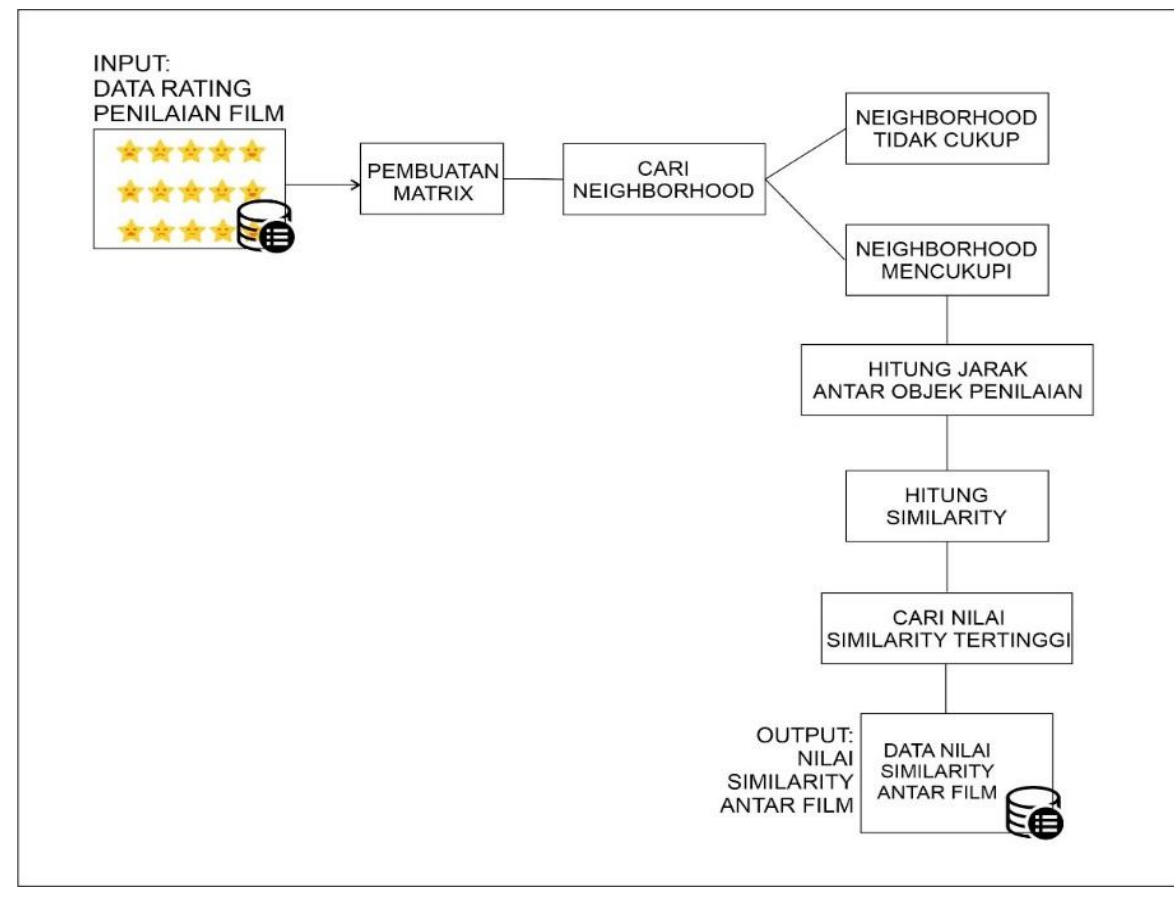

Gambar 3

Flow Pembuatan Rekomendasi Berdasarkan Item-based Collaborative Filtering

Hal yang membedakan pembuatan rekomendasi berdasarkan user-based collaborative filtering dan item-based collaborative filtering terletak pada neighborhood yang digunakan. Item-based collaborative filtering membuat rekomendasi dengan memperhitungkan jarak antar item-neighborhood, item-neighborhood merupakan data penilaian film dengan film lainnya yang dinilai oleh pengguna yang sama. Setelah didapatkan jarak antar item-neighborhood, sistem akan menghitung nilai similarity berdasarkan jarak rata-rata antar item-neighborhood per item. Nilai similarity diurutkan dari yang tertinggi, nilai similarity yang tinggi menandakan bahwa hubungan antar film yang dihitung semakin mirip. Film-film yang memiliki nilai kemiripan tertinggi akan ditampilkan sebagai rekomendasi "more like this" yang akan ditampilkan pada halaman detil film. 


\section{UML DIAGRAMS}

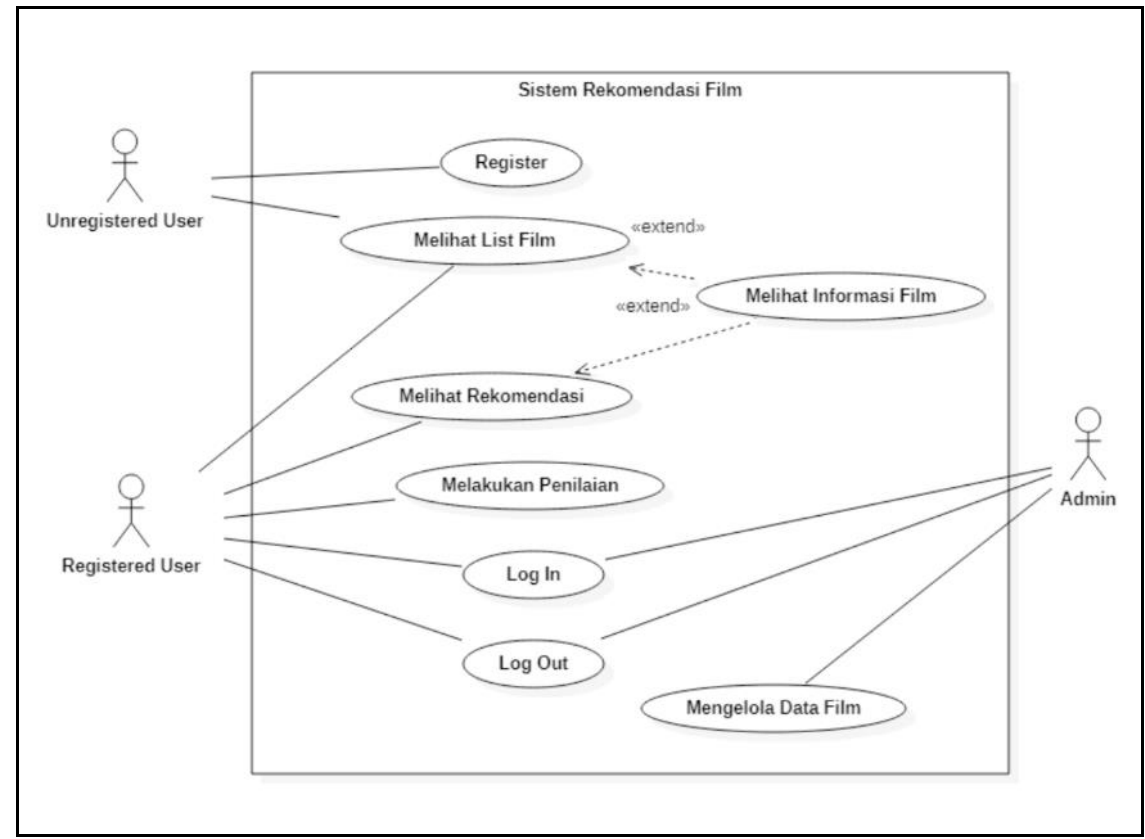

Gambar 4

Use Case Diagram

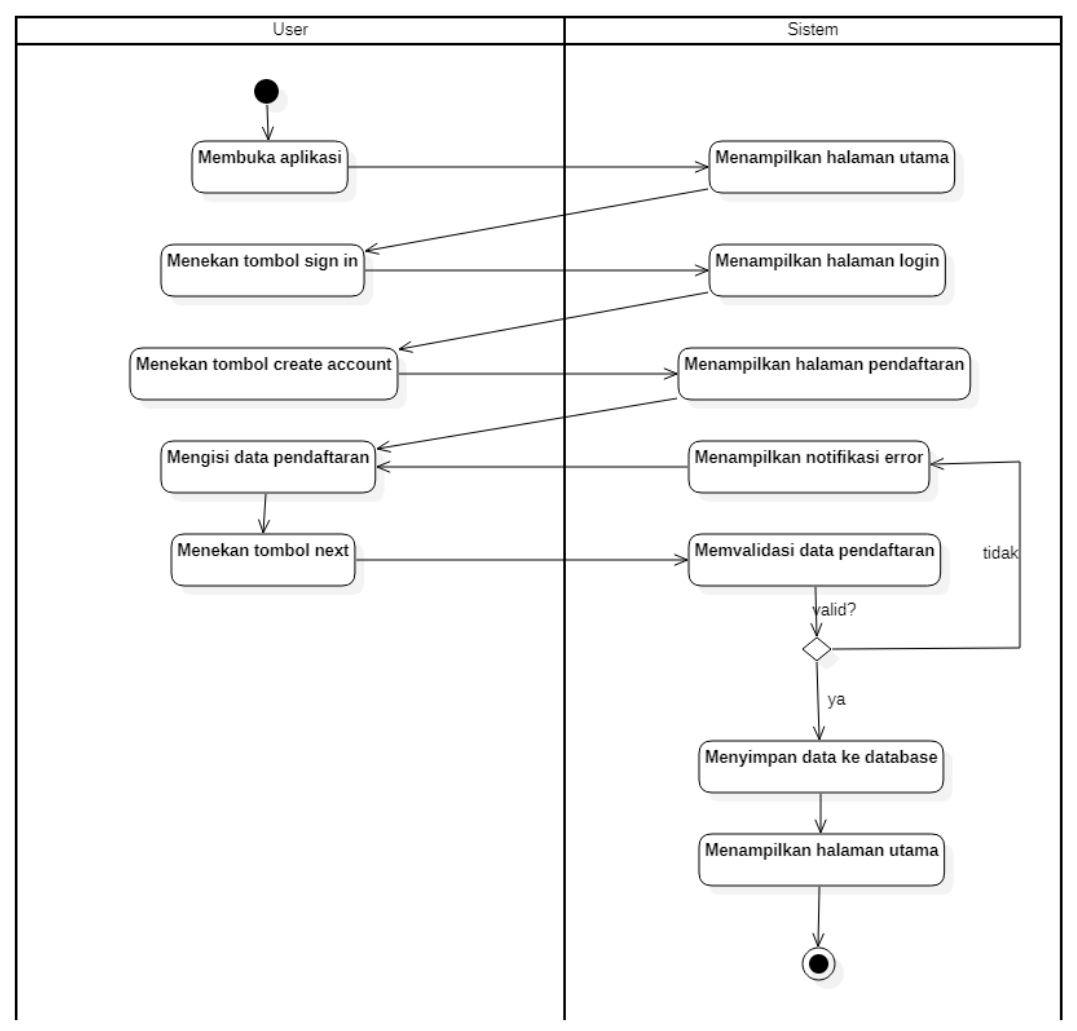

Gambar 5

Activity Diagram Registrasi 


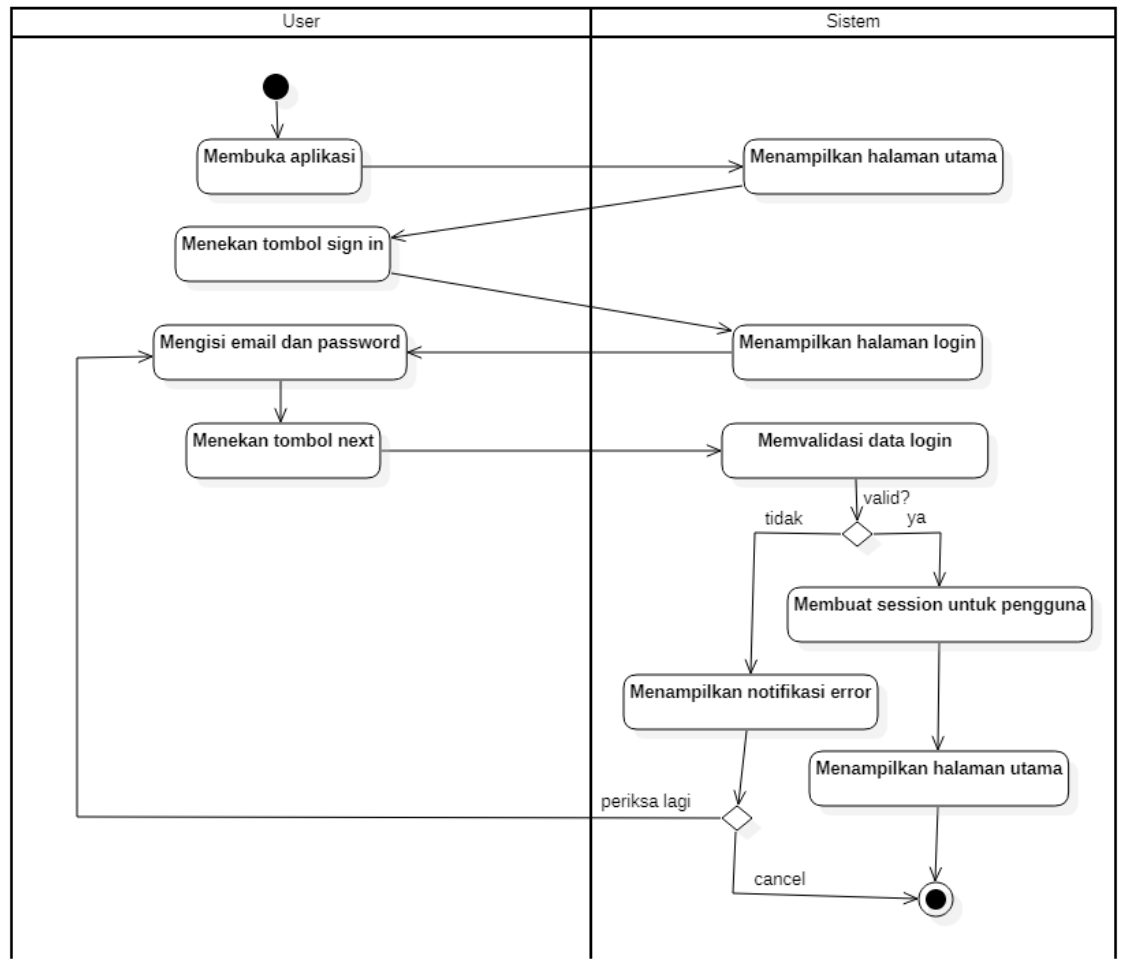

Gambar 6

Activity Diagaram Login

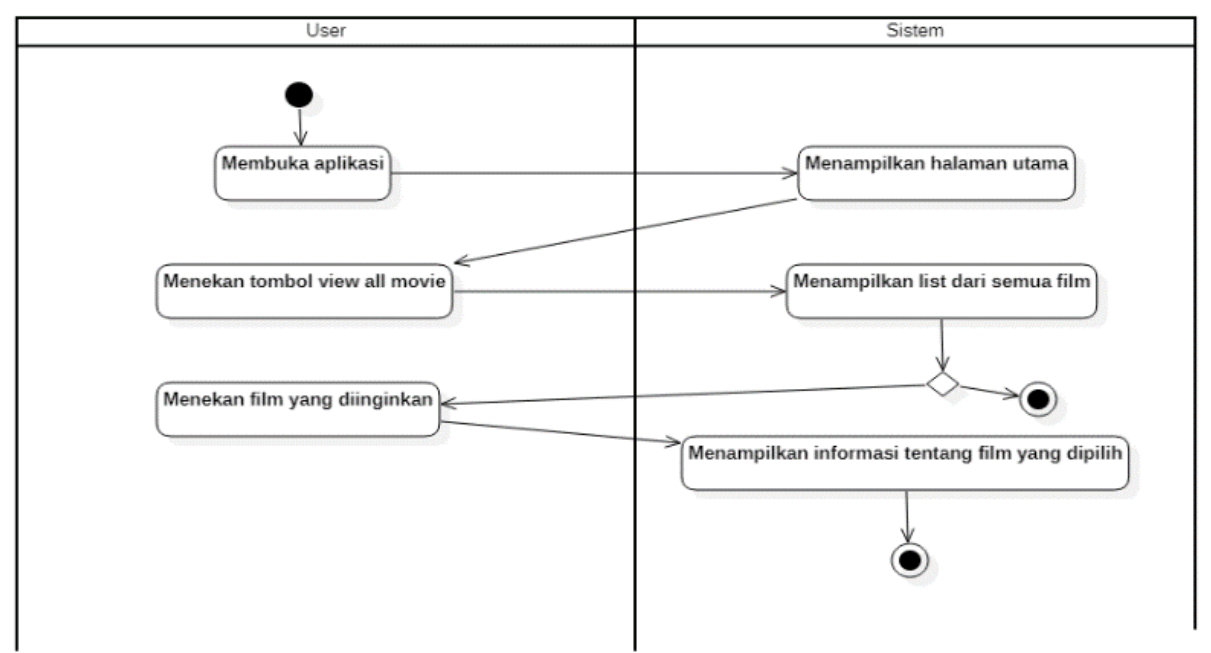

Gambar 7

Activity Diagram Melihat List Film 


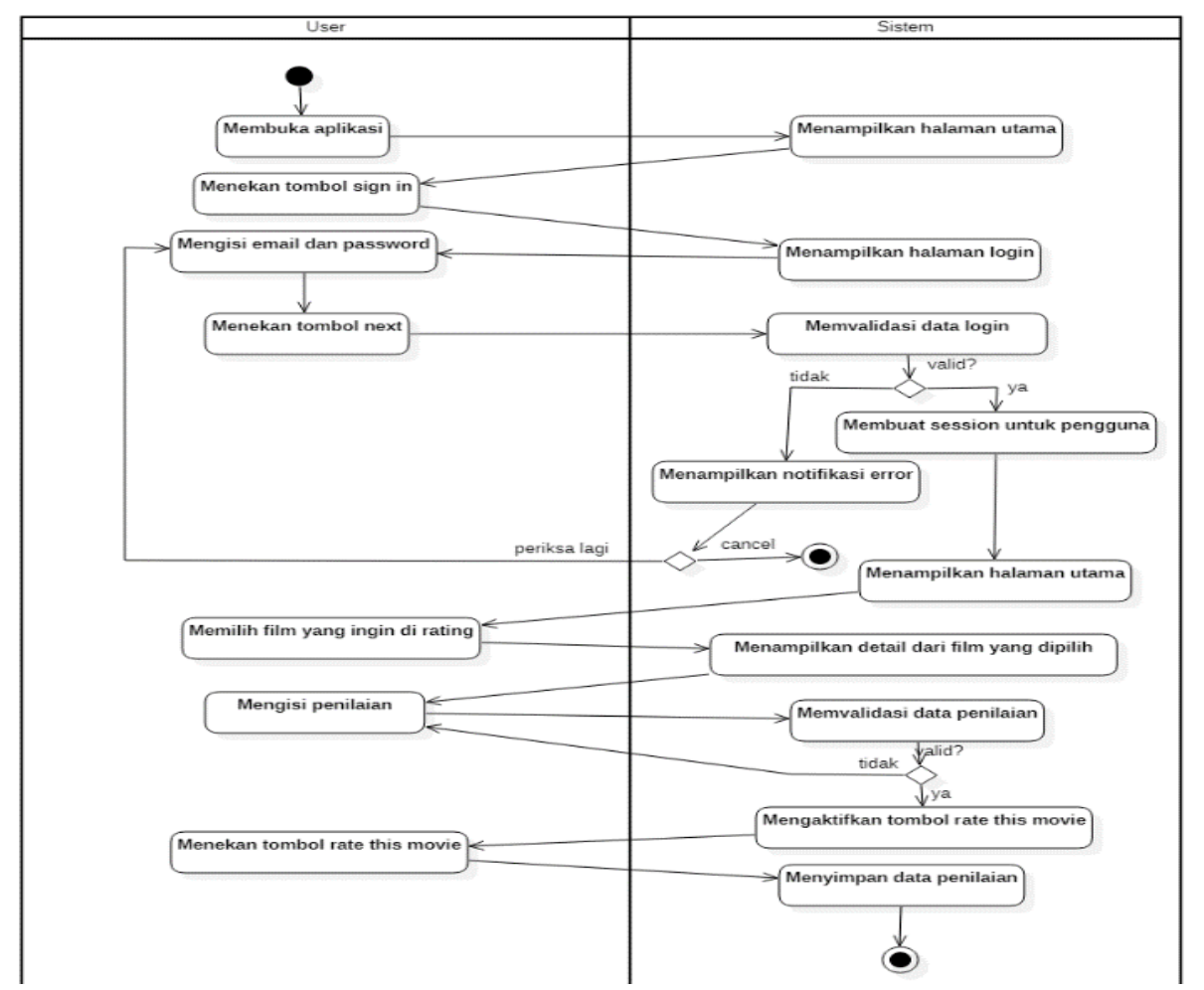

Gambar 8

Activity Diagram Melakukan Penilaian

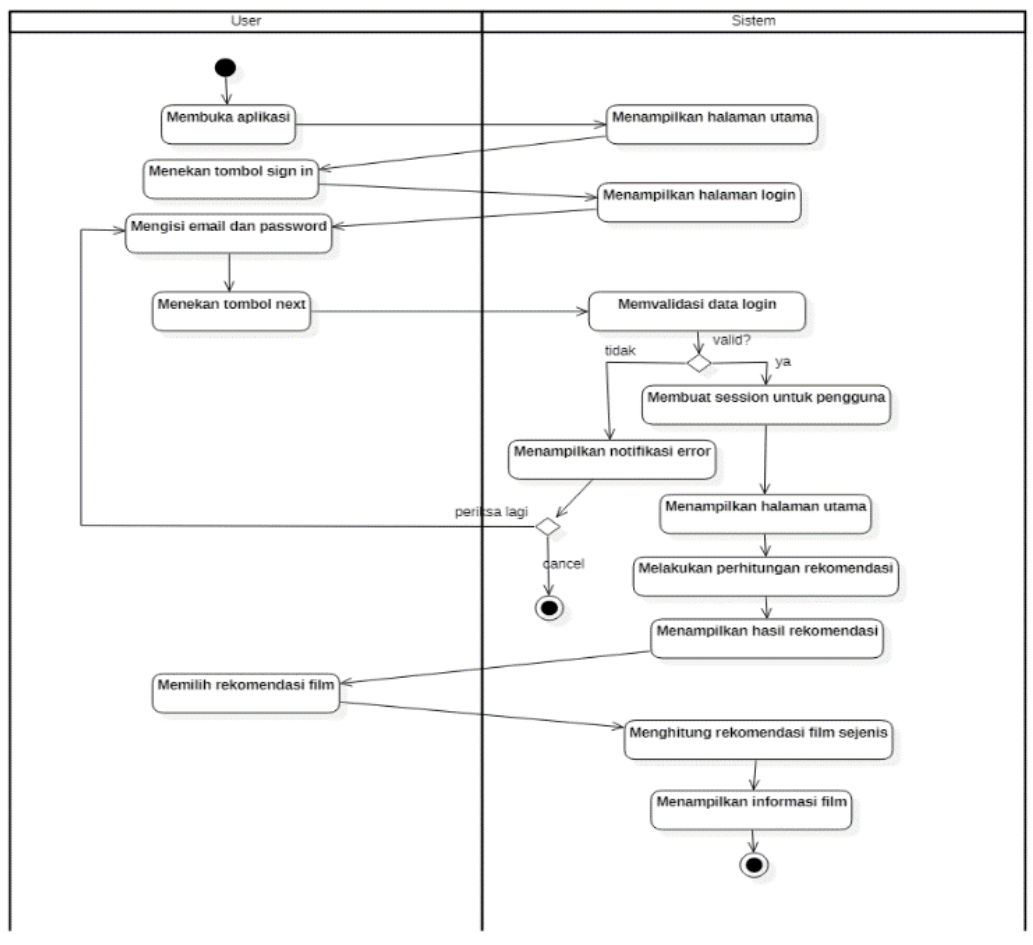

Gambar 9

Activity Melihat Rekomendasi 
Menggunakan Metode Collaborative Filtering

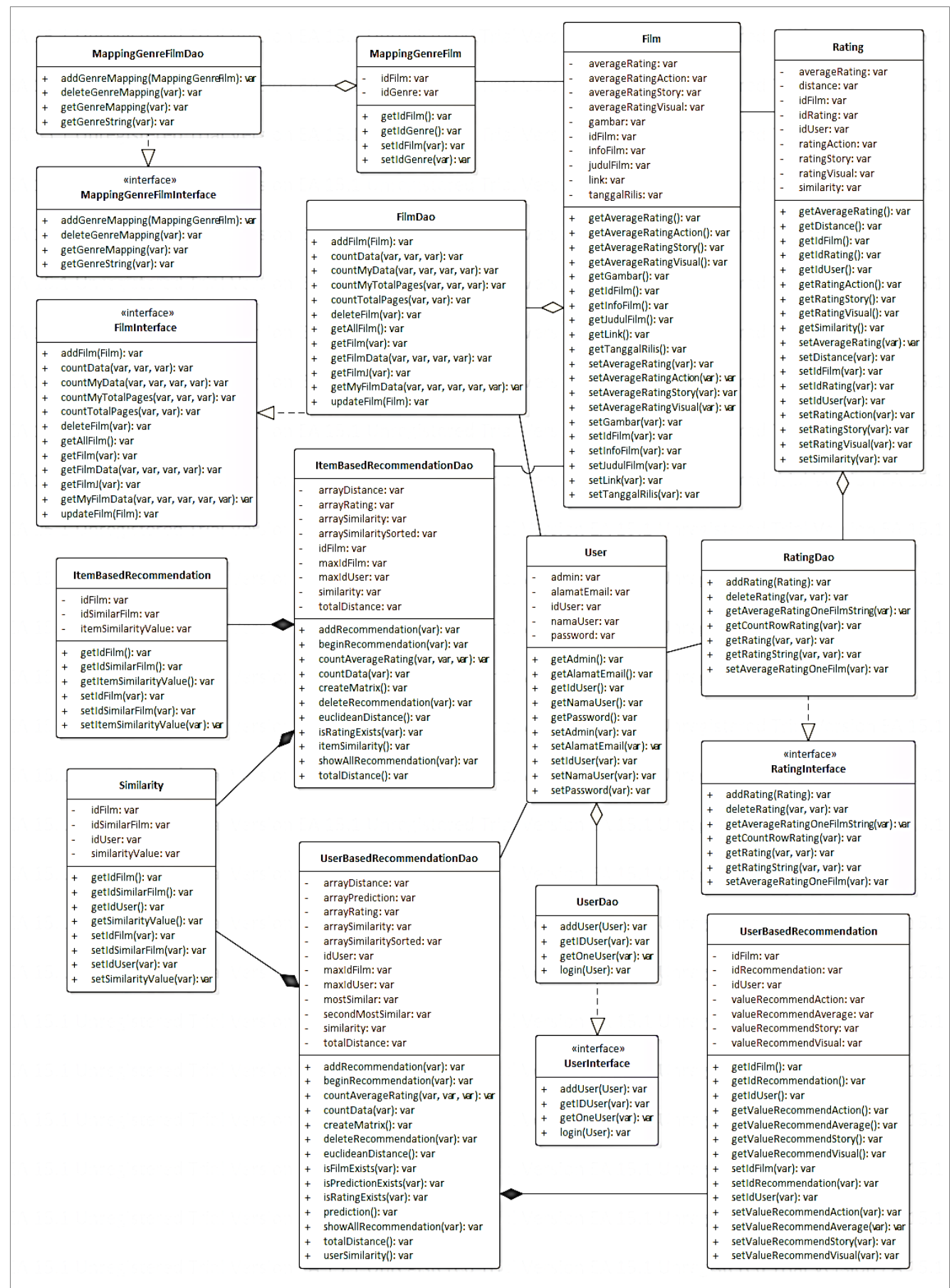

Gambar 10

Class Diagram 
5. RANCANGAN ANTAR MUKA

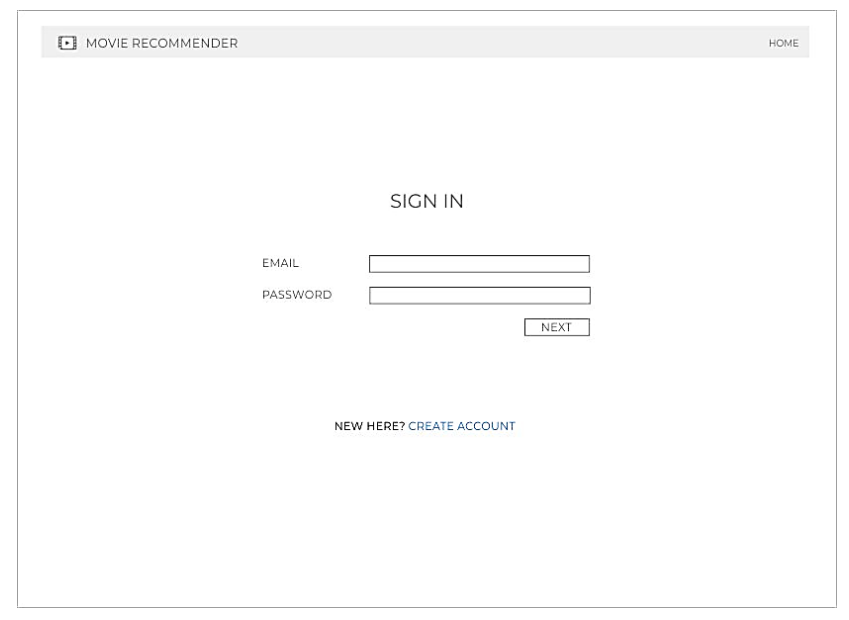

Gambar 11

Sign In / Log In (All User)

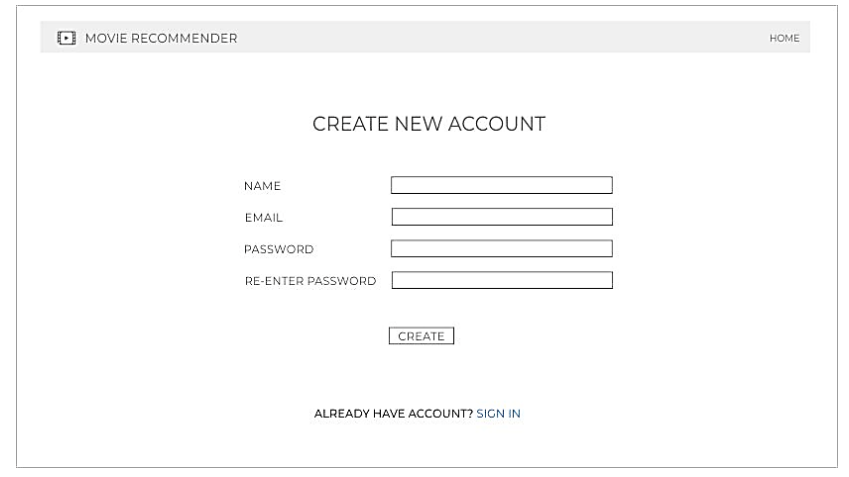

Gambar 12

Halaman Create Account / Register (Unregistered User) 


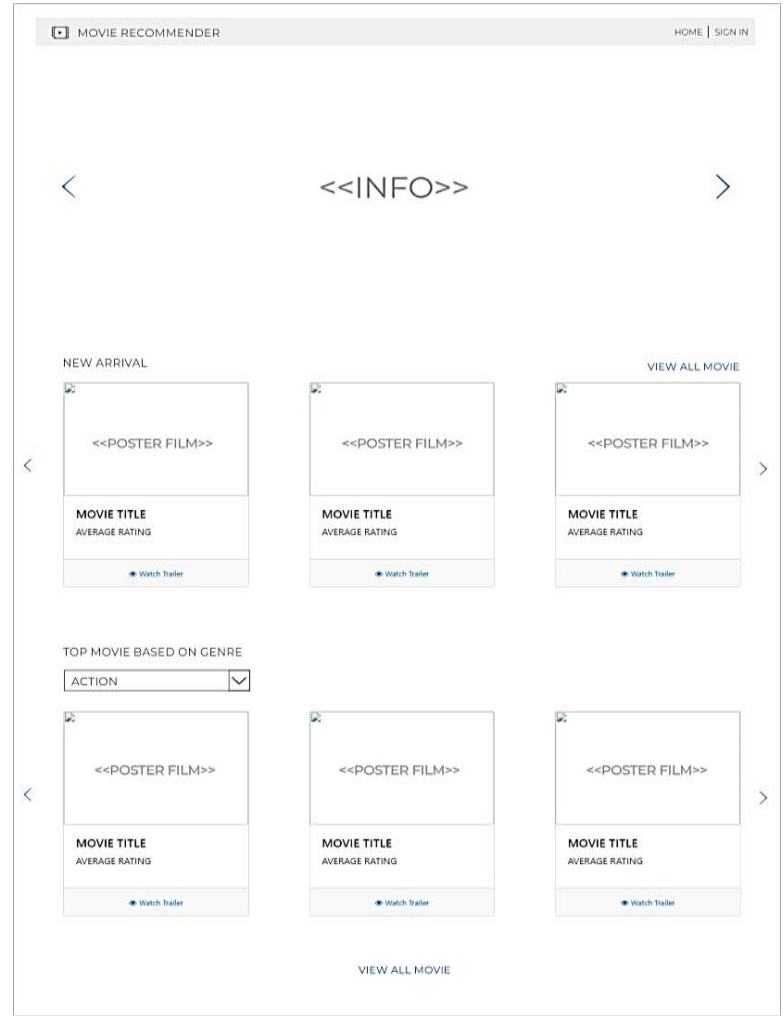

Gambar 13

Halaman Utama (Unregistered User)

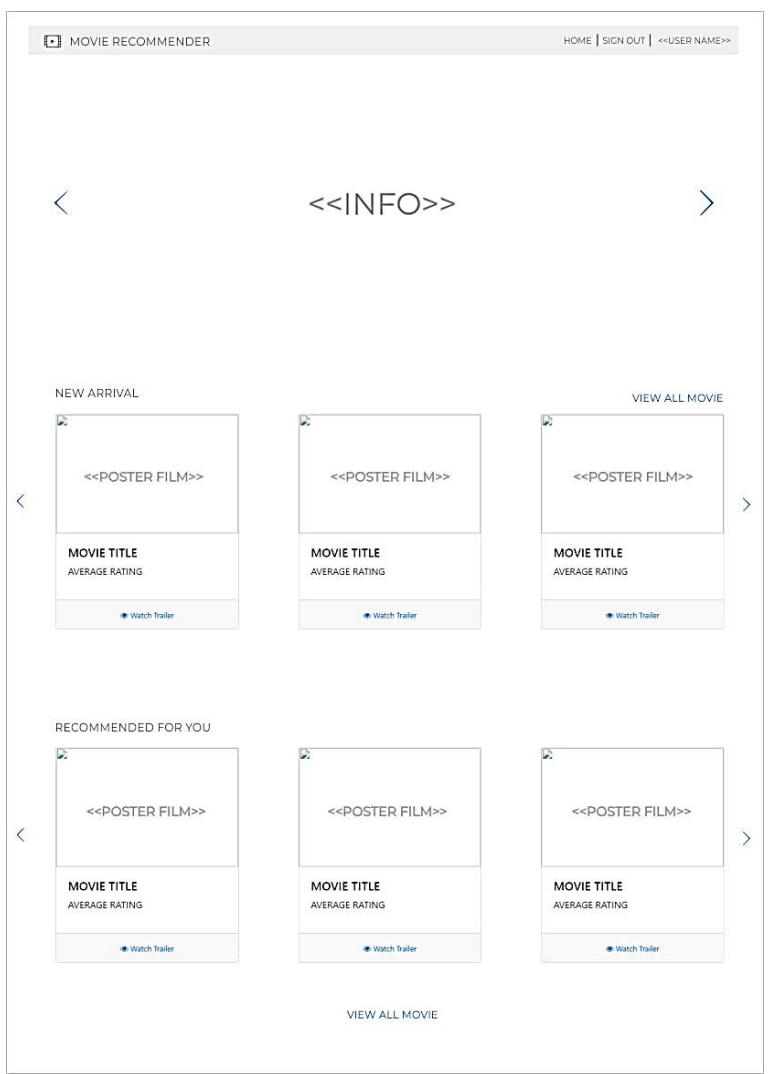

Gambar 14

Halaman Utama (Registered User) 


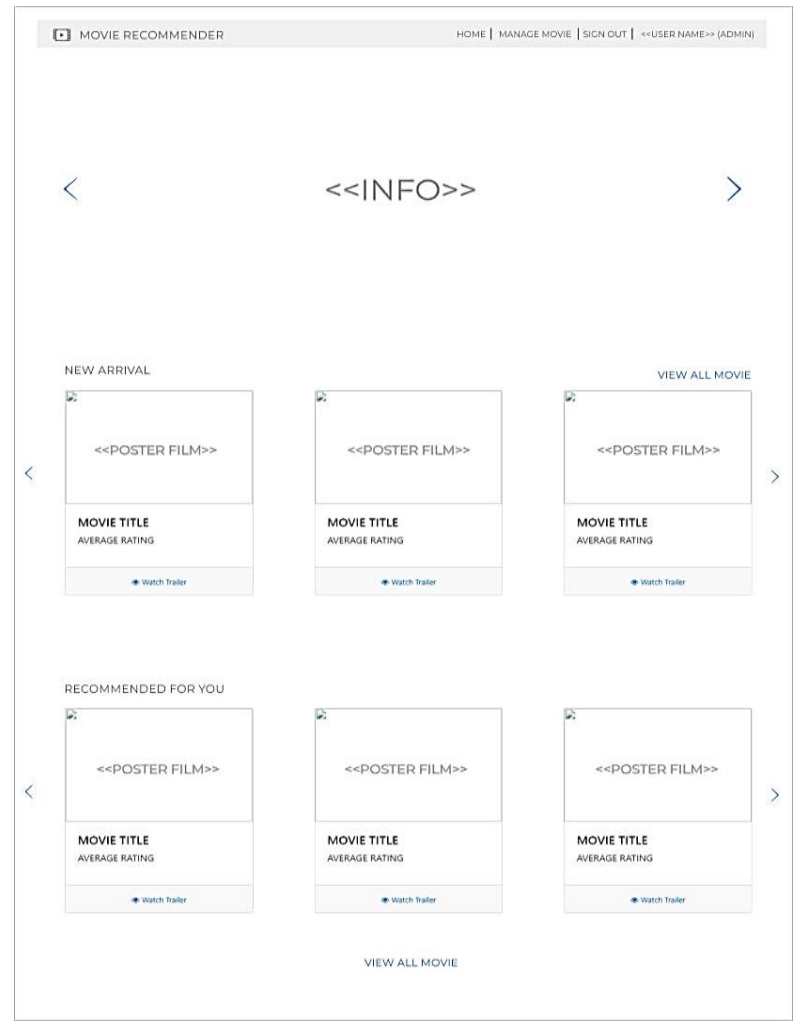

Gambar 15

Halaman Utama (Admin)

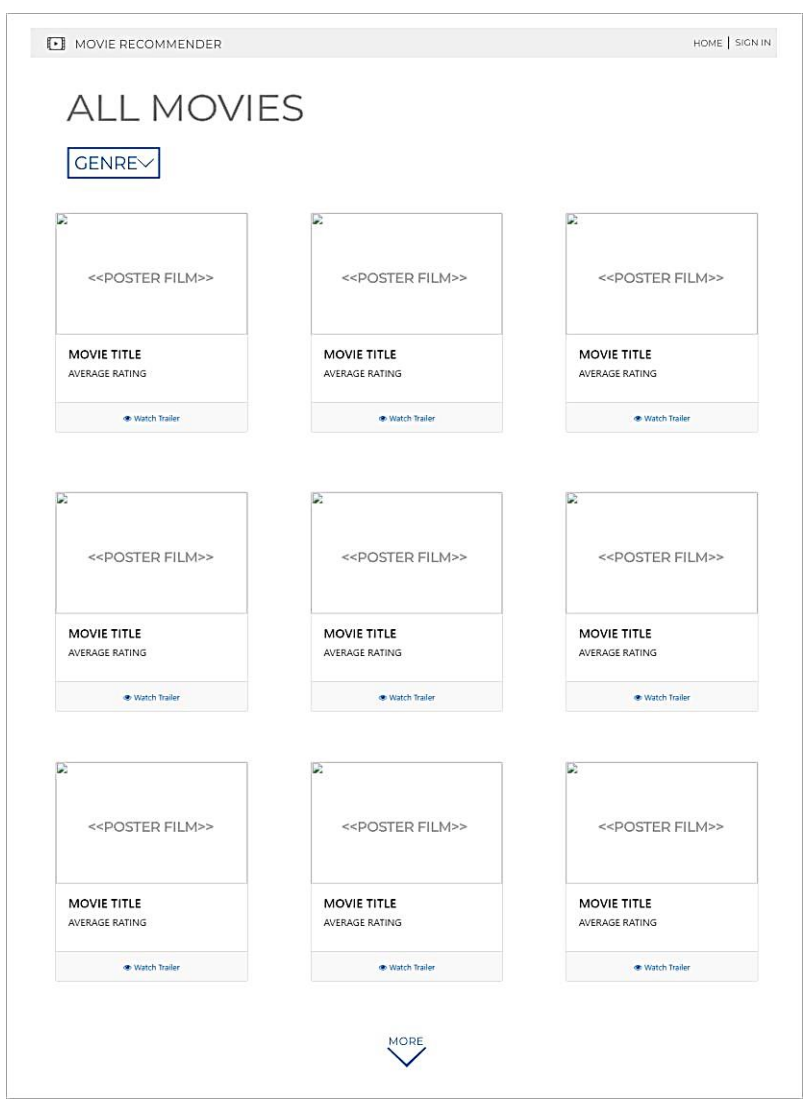

Gambar 16

View All Movie (Unregistered User) 
DI MOVIE RECOMMENDER

HOME | SICN OUT | «USER NAME»

ALL MOVIES

GENREY
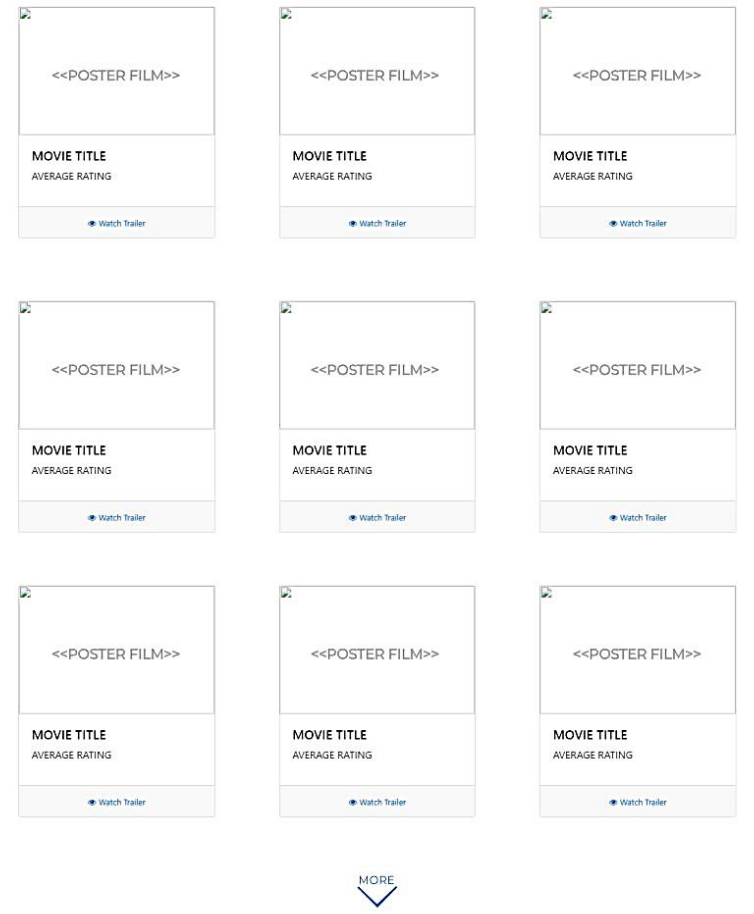

Gambar 17

View All Movie (Registered User)

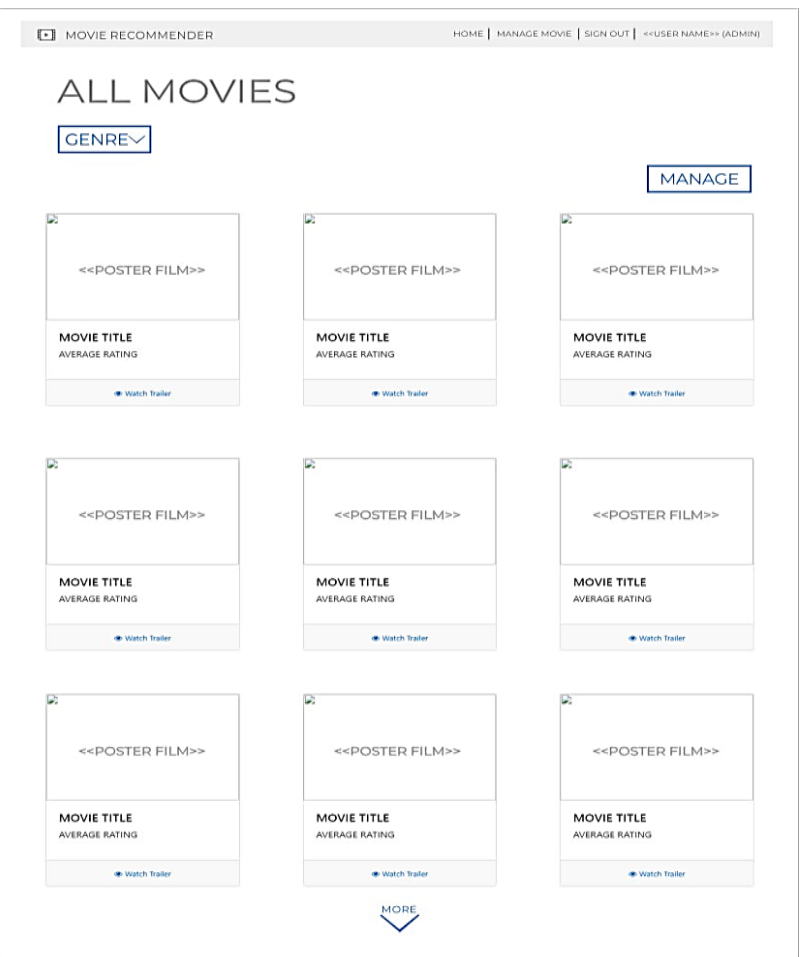

Gambar 18

View All Movie (Admin) 


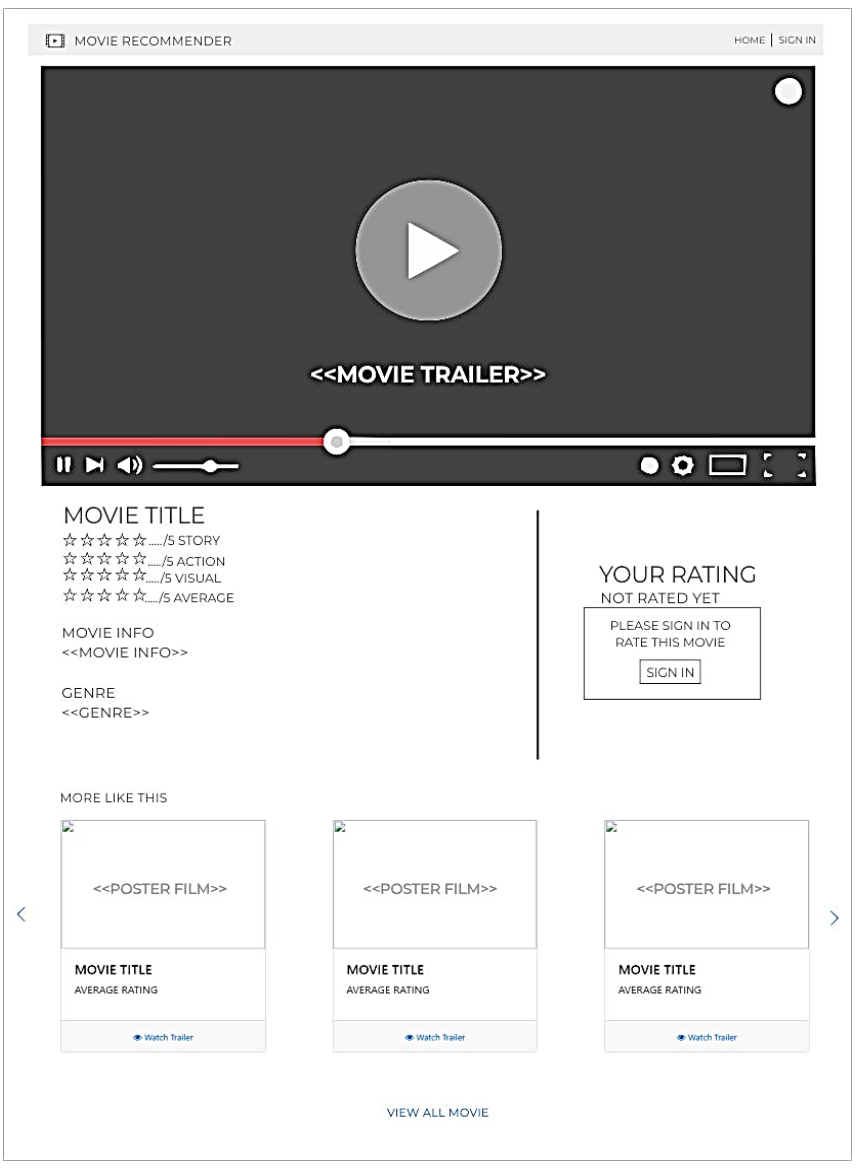

Gambar 19

Movie Detail (Unregistered User)

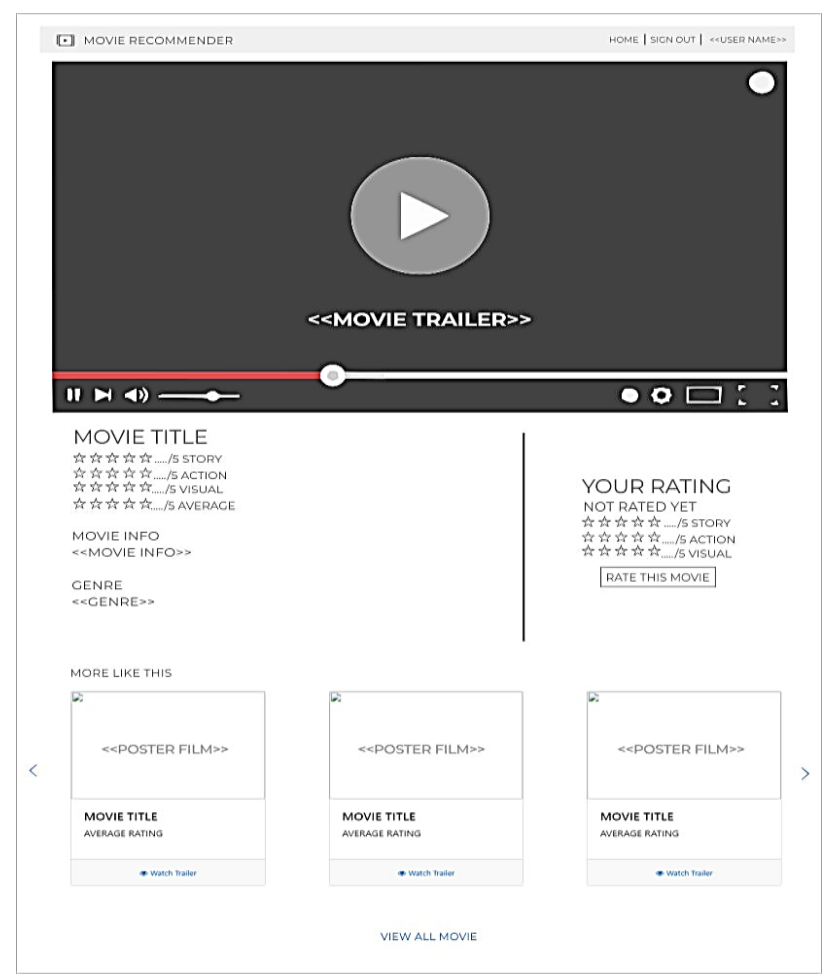

Gambar 20

Movie Detail (Registered User) 


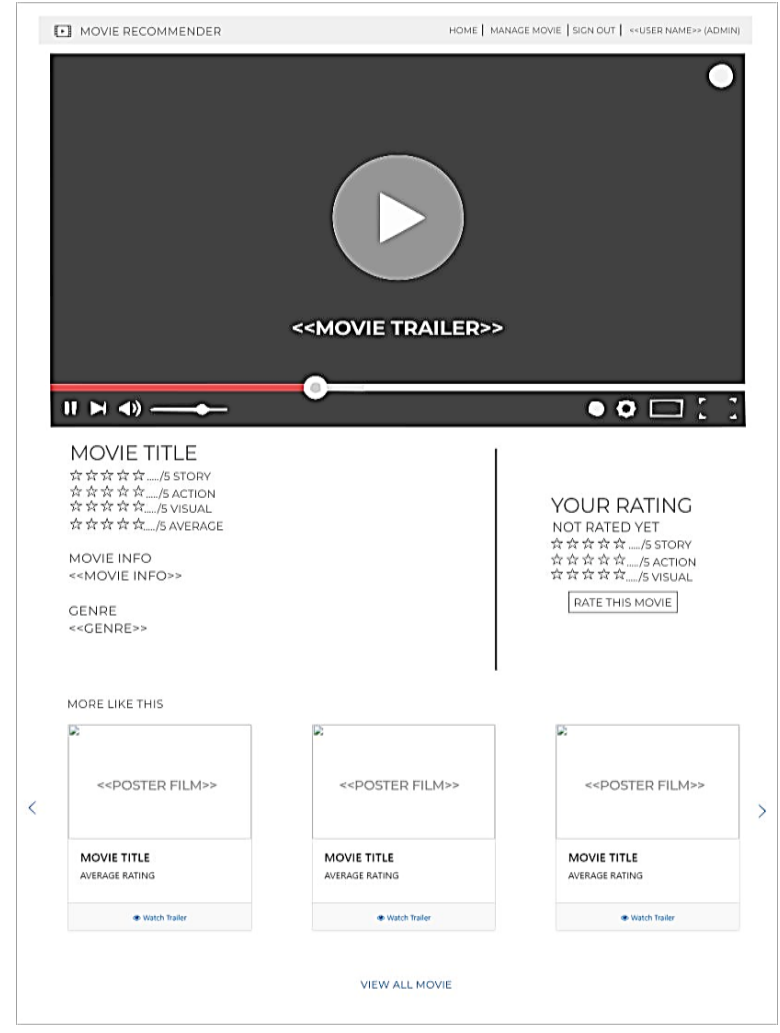

Gambar 21

Movie Detail (Admin)

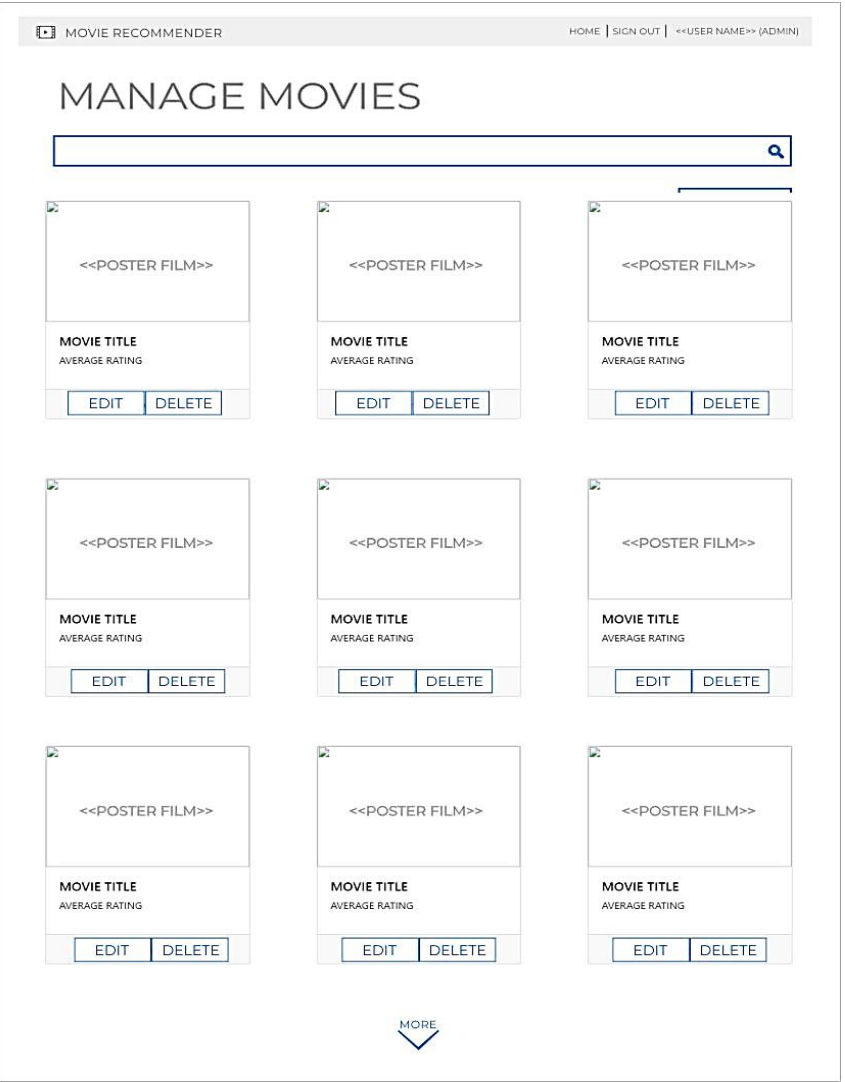

Gambar 22

Manage Movie Database (Admin) 


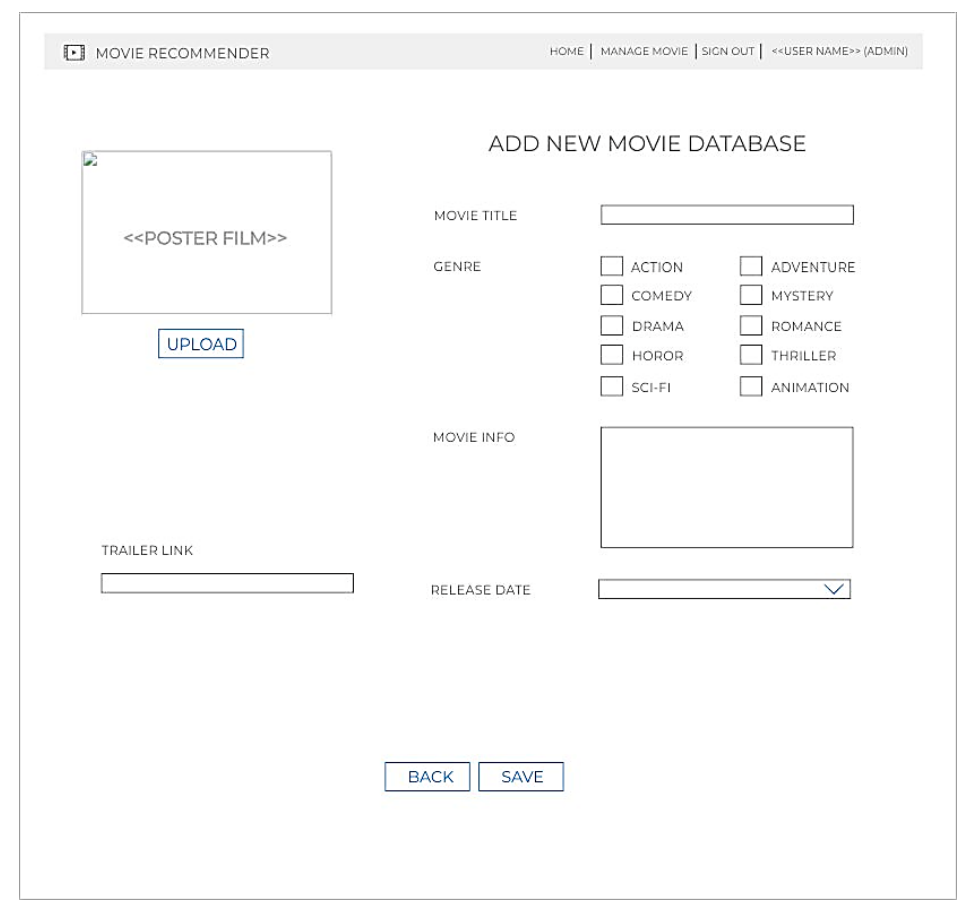

Gambar 23

Add New Movie Database (Admin)

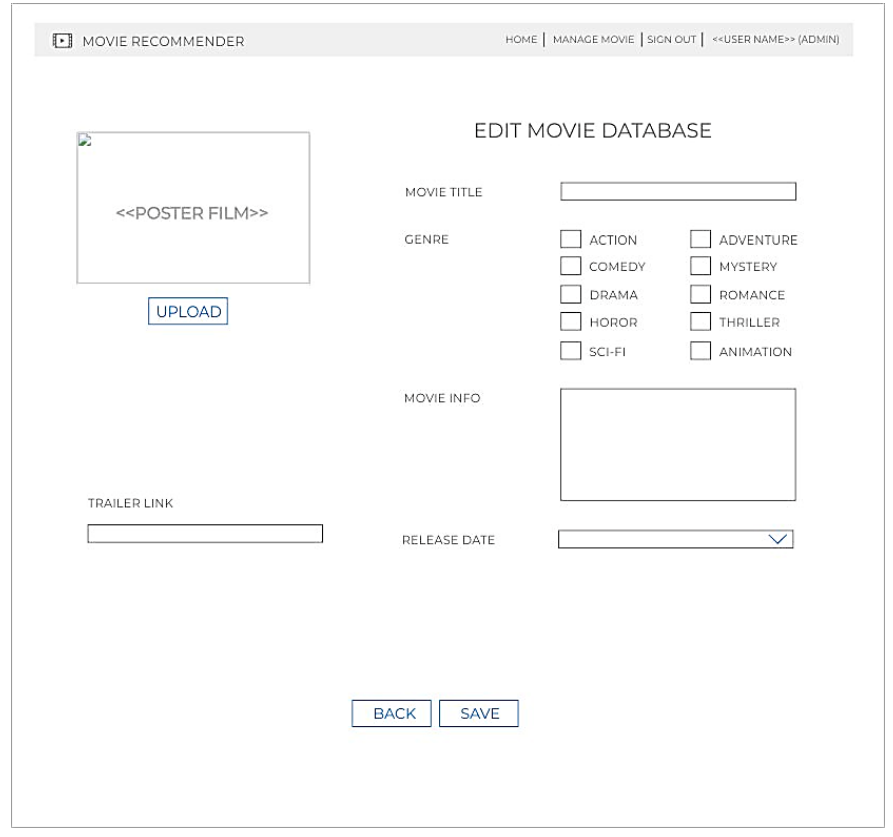

Gambar 24

Edit Movie Database (Admin) 


\section{KESIMPULAN}

a. Pembuatan sistem rekomendasi dapat dilakukan dengan bahasa pemograman $P H P$ dan HTML5.

b. Rekomendasi berdasarkan user-based collaborative filtering dapat dihitung dengan mencari kemiripan antar pengguna dengan menggunakan rumus euclidean distance dan similarity-based prediction untuk perhitungan prediksi rating, yang hasilnya bisa menentukan rekomendasi seorang pengguna berdasarkan rating dari pengguna lain yang memiliki ketertarikan sejenis.

c. Rekomendasi berdasarkan item-based collaborative filtering dapat dihitung dengan mencari kemiripan antar item.

d. Sistem rekomendasi collaborative filtering berkerja seolah - olah seperti mengelompokan pengguna dengan berbagai kategori minat.

e. Sistem rekomendasi collaborative filtering mampu memberikan informasi rekomendasi kepada pengguna berdasarkan rating tanpa menganalisis konten pada item. Sistem rekomendasi collaborative filtering mampu mengelompokan item berdasarkan kategori tertentu yang terbentuk dari perhitungan atau pembelajaran interaksi pengguna terhadap item salah satunya rating.

\section{DAFTAR PUSTAKA}

[1] Gandhi, S. R., \& Gheewala, P. (2017). A Survey on Recommendation System with Collaborative Filtering using Big Data. International Conference on Innovative Mechanisms for Industry Applications.

[2] Giusti, R., \& Batista, G. E. (2013). An Empirical Comparison of Dissimilarity Measures for Time Series Classification. 2013 Brazilian Conference on Intelligent Systems.

[3] Jia, Z., Yang, Y., Gao, W., \& Chen, X. (2015). User-based Collaborative Filtering for Tourist Attraction Recommendations. 2015 IEEE International Conference on Computational Intelligence \& Communication Technology.

[4] Liu, L., Mehandjiev, N., \& Xu, D.-L. (2011). Multi-Criteria Service Recommendation Based on User Criteria Preferences. Proceedings of the Fifth ACM Conference on Recommender Systems.

[5] Ricci, F., Rokach, L., \& Shapira, B. (2011). Recommender Systems Handbook. Berlin/Heidelberg: Springer Science+Business Media.

[6] Suteja, B. R., \& Guritno, S. (2017). A recommendation system for culinary tourists in Jogjakarta based on collaborative filtering. 2017 Second International Conference on Informatics and Computing (ICIC).

[7] Sun, L., \& Huang, M. (2013). An Improved Collaborative Filtering Algorithm Based on Sparse Dataset's Optimization with User's Browser Information. 2013 10th Web Information System and Application Conference.

[8] Wiranto, Winarko, E., Hartati, S., \& Wardoyo, R. (2014). Improving the Prediction Accuracy of Multicriteria Collaborative Filtering by Combination Algorithms. (IJACSA) International Journal of Advanced Computer Science and Applications. 